\title{
Molecular cloning, expression, and regulation of estrogen receptors in pigeon oviduct epithelial cells
}

H. Zhang ${ }^{1,2}$, F. Chen ${ }^{1,2}$, G.L. Li ${ }^{3}$, Y.Y. Ding ${ }^{3}$, Z.R. Tao ${ }^{1}$, J.J. Li ${ }^{1}$, S.L. Zhong ${ }^{4}$ and L.Z. Lu ${ }^{1}$

${ }^{1}$ Institute of Animal Husbandry and Veterinary Science, Zhejiang Academy of Agricultural Sciences, Hangzhou, Zhejiang, China ${ }^{2}$ College of Animal Sciences, Nanjing Agriculture University, Nanjing, Jiangsu, China ${ }^{3}$ Ping Yang Science and Technology Bureau, Wenzhou, Zhejiang, China ${ }^{4}$ Ping Yang XingLiang Pigeon Farming Co. Ltd., Wenzhou, Zhejiang, China

Corresponding author: L.Z. Lu

E-mail: lulizhibox@163.com

Genet. Mol. Res. 13 (1): 1926-1937 (2014)

Received January 23, 2013

Accepted August 20, 2013

Published March 17, 2014

DOI http://dx.doi.org/10.4238/2014.March.17.20

\begin{abstract}
Estrogen regulates reproductive behavior and drives the proliferation and differentiation of several cell types. These physiological functions of estrogen are mediated by estrogen receptors (ERs), and each ER isoform plays a distinct role. To clarify the molecular mechanism of estrogen action and to evaluate the effect of ERs on the secretion of ovalbumin (OVA) in pigeon oviduct epithelial cells (POECs), we determined the complete coding sequences encoding ER alpha $(E R \alpha)$ and ER beta $(E R \beta)$ in pigeons. The abundance of pigeon ER $\alpha$ and ER $\beta$ mRNA was detected using quantitative polymerase chain reaction. These results revealed that pigeon ER $\alpha$ is highly expressed in the oviduct, while pigeon ER $\beta$ is highly expressed in the ovary and kidney. We hypothesize that ER $\alpha$ mRNA predominates over that of ER $\beta$ in the oviduct. The expression of ER $\alpha$ can be down-
\end{abstract}


regulated by $17 \beta$-estradiol, and the knockdown of ER $\alpha$ promoted OVA mRNA expression in cultured POECs, indicating that ER $\alpha$ may play an important role in OVA secretion.

Key words: Estrogen receptor; Estrogen expression; siRNA; Estrogen regulation; Oviduct epithelial cells

\section{INTRODUCTION}

Estrogen receptors (ERs) are members of the nuclear receptor superfamily that mediates the physiological functions of estrogen. Human ER alpha $(\mathrm{ER} \alpha)$ and rat ER beta (ER $\beta)$ were cloned and sequenced in 1986 by Green et al. and in 1996 by Kuiper et al., respectively. Since the discovery of ER $\beta$, the mechanisms of action of estrogen have been reevaluated (Nilsson et al., 2001). As members of the nuclear receptor family, both ERs share a common structural architecture. They are composed of six functional domains, A to F, on the basis of conserved regions upon comparison of $E R \alpha$ amino acid sequences of several species (Krust et al., 1986). Estrogen binding to ER homodimers/heterodimers can lead to a change in the transcription rate of target genes. In avian species, the cDNA sequence of chicken ER $\alpha$ was first cloned in 1986 by Krust et al. and quail ER $\beta$ was cloned in 1998 by Lakaye et al. The cDNA sequences of pigeon (Columba livia) ERs have not yet been reported.

Recent studies have characterized the expression of ER $\alpha$ and ER $\beta$ in various tissues (Bookout et al., 2006; Chen et al., 2011), revealing that differences in the expression of the two ER isoforms induce gene regulation. Both ER subtypes are present in multiple human tissues: $E R \alpha$ is highly expressed in the uterus, while ER $\beta$ is mainly expressed in the ovary (Bookout et al., 2006). Furthermore, expression of the ER $\beta$ protein fluctuates during the estrous cycle in rat ovaries (Hiroi et al., 1999). To date, the relative tissue expression pattern of ERs has been limited to a few reports in avian species.

The ability of estrogen to modulate ER $\alpha$ expression has been most extensively studied in cell lines (Treilleux et al., 1997; Robertson et al., 2002). One hypothesis suggests that estrogen induces trans-acting factors to bind to specific elements of ER mRNA molecules, and protects their ends. The mRNA of ERs has an unstable 3'-untranslated region (UTR) that exceeds 4000 bases. The 3'-UTR contains several AUUUA sites, which are typically present in unstable oncogene mRNAs (Peng et al., 1996; Kenealy et al., 2000). Estrogen may stabilize endometrial ER mRNAs by inducing proteins to bind to specific sequences in the 3'-UTR. However, studies show that treatment with estrogen induces down-regulation of ER $\alpha$ mRNA that appears to be caused by its reduced stability (Borras et al., 1994; Saceda et al., 1998). Relatively little is known about the ability of estrogen to regulate the expression of ERs in pigeon oviduct epithelial cells (POECs).

In chickens, ovalbumin (OVA), the major constituent of egg white, is synthesized in the oviduct under estrogenic induction (Kohler et al., 1969; Palmiter and Wrenn, 1971), and its 5'-flanking region contains a corresponding DNA recognition sequence (AGGTGA) that is recognized by the ER $\alpha$ and ER $\beta$ P-box (CEGCKA) (Glass, 1994). Thus, we deduced that ERs have a certain function in the expression of OVA mRNA, although the role that ERs play in the expression of OVA in POECs is unknown.

The pigeon $(C$. livia), an important domestic species worldwide, is an altricial bird and a good model to study the pattern of reproduction in avian species in which both parents 
participate in the care of eggs and youngs. The main objectives of this study were to isolate the full-length pigeon ER $\alpha$ and ER $\beta$ mRNA, and to examine the expression profiles of these two receptors in various tissues. Furthermore, we investigated whether the expression of pigeon ER $\alpha$ might be regulated by estrogen in vitro, and the potential role of ER $\alpha$ in expression regulation of OVA mRNA in POECs.

\section{MATERIAL AND METHODS}

\section{Experimental animals}

One 15-month-old female King Pigeon was killed, and its oviduct and ovary were collected for cloning and sequencing of ER cDNA. Eight 2-year-old female King Pigeons were used for quantitative polymerase chain reaction (qPCR) analysis. Fifteen tissues (oviduct, ovary, heart, liver, spleen, lung, kidney, abdominal fat, stomach, skeletal muscle, hypothalamus, brain, intestine, craw, and pancreas) were collected, immediately frozen in liquid nitrogen, and stored at $-70^{\circ} \mathrm{C}$ until total RNA was extracted. All pigeons used in experiments were cared for and slaughtered following standard ethical practices.

\section{Cell culture}

POECs were isolated based on methods described in Jung et al. (2011) and Kasperczyk et al. (2012), with some modifications. Oviduct tissue was collected from a 5-month-old laying-period pigeon that had not been stimulated with hormones. The infundibulum, magnum segments from the oviduct of pigeons was dissected, and the surface of the oviduct was carefully removed, along with mucosa and blood vessels. The manicured tissue was washed in phosphate-buffered saline containing $200 \mathrm{U}$ penicillin and $200 \mathrm{U}$ streptomycin, and cut into 1 - to $2-\mathrm{mm}^{3}$ pieces. Subsequently, the pieces were digested with $1 \mathrm{mg} / \mathrm{mL}$ collagenase type I for $50 \mathrm{~min}$ at $37^{\circ} \mathrm{C}$ in a shaking water bath. The dissociated cells were filtered through a $150-$ $\mu \mathrm{m}$ copper sieve, and the filtered cells were centrifuged at $1000 \mathrm{rpm}$ for $8 \mathrm{~min}$ and washed in Dulbecco's modified Eagle's medium (DMEM)-F12 media. The differential adhesion method was used to retrieve the purified POECs. Cells were seeded onto 24-well cell culture plates at a density of $4 \times 10^{6}$ cells $/ \mathrm{cm}^{2}$. Purified POECs were cultured with DMEM-F12 medium (Invitrogen, Carlsbad, CA, USA) containing 10\% fetal bovine serum, antibiotics (100 U penicillin $+100 \mathrm{U}$ streptomycin), $40 \mathrm{ng} / \mathrm{L}$ epidermal growth factor, $20 \mu \mathrm{g} / \mathrm{L}$ insulin, and 10 $\mu \mathrm{g} / \mathrm{L}$ glutamine in an incubator with $5 \% \mathrm{CO}_{2}$ at $37^{\circ} \mathrm{C}$. Furthermore, $17 \beta$-estradiol was added to the medium to assess its effect on the expression of pigeon $\mathrm{ER} \alpha$.

Short interfering RNA (siRNA) transfection was performed on 24-well plates. Predesigned siRNA for pigeon ER $\alpha$ (Genepharma, Shanghai, China) was transfected in primary cultured POECs using Lipofectamine ${ }^{\mathrm{TM}} 2000$ Transfection Reagent (Invitrogen) according to the manufacturer protocol. The cells were harvested for RNA extraction $24 \mathrm{~h}$ after transfection.

\section{Total RNA extraction and reverse transcription}

Total RNA was extracted using TRIzol reagent (Takara, Osaka, Japan) according to the manufacturer protocol and treated with recombinant DNase I (Takara). The cDNAs used 
for cloning and sequencing were synthesized using the SMARTer ${ }^{\mathrm{TM}}$ RACE cDNA Amplification Kit (Clontech, Mountain View, CA, USA). M-MLV reverse transcriptase (Takara) was used to synthesize cDNA for qPCR.

\section{Molecular cloning}

Three primer pairs, ER $\alpha 1 \mathrm{~F} / 1 \mathrm{R}, \mathrm{ER} \alpha 2 \mathrm{~F} / 2 \mathrm{R}$, and $\mathrm{ER} \alpha 3 \mathrm{~F} / 3 \mathrm{R}$, were designed according to multiple alignments of reported mRNA sequences of $E R \alpha$. Three overlapping fragments of the pigeon ER $\alpha$ were amplified by these primer pairs in oviduct tissue.

Using cDNA transcribed from the ovary as a template, two overlapping fragments of the pigeon ER $\beta$ were amplified by the primer pairs $E R \beta 1 F / 1 R$ and $E R \beta 2 F / 2 R$. The full-length pigeon ER $\beta$ was obtained using rapid amplification of cDNA ends (RACE) with the SMART RACE cDNA Amplification Kit (Clontech) according to the manufacturer protocol. All primer pairs used in this study are shown in Table 1.

\begin{tabular}{|c|c|c|c|c|}
\hline Primer & Binding sites & Nucleotide sequence & Size (bp) & AT $\left({ }^{\circ} \mathrm{C}\right)$ \\
\hline ER $\alpha 1 F$ & $\mathrm{nt} 177-196^{\mathrm{a}}$ & TCCTTGCTCACTGCCATTAG & 598 & 54.8 \\
\hline ER $\alpha 1 R$ & nt756-774 & CCCATAGTGGTAGCCTGAA & & \\
\hline ER $\alpha 2 \mathrm{~F}$ & nt564-588 & ACCСТACTACCTTGAAAATGAACAG & 876 & 56.2 \\
\hline $\mathrm{ER} \alpha 2 \mathrm{R}$ & nt1416-1439a & CCCTCTACACATTTCCCTTGATTC & & \\
\hline $\mathrm{ER} \alpha 3 \mathrm{~F}$ & nt1177-1196a & CTATGGGGTCTGGTCTTGTGAGG & 833 & 52 \\
\hline ER $\alpha 3 R$ & nt1986-2009a & CTGCTGGGTTTCTCATACCATTAT & & \\
\hline ER $\beta 1 F$ & nt796-814b & ACATCTGCCCAGCTACCAA & 301 & 58 \\
\hline ER $\beta 1 R$ & nt1078-1096 b & CTAGGACGACTCACCAACA & & \\
\hline ER $\beta 2 F$ & nt1014-1034 b & СТCCTCAGCACAGTCAGTCCA & 495 & 56 \\
\hline ER $\beta 2 R$ & nt $1488-1508^{b}$ & TTTCCTGTTGCTTTCGGGTTC & & \\
\hline ER $\beta 5 \mathrm{GSP}$ & nt983-1008 & СTTCTTGAGCCACATTTCATCATTCC & 1008 & 72 \\
\hline ER $\beta 3 \mathrm{GSP}$ & $\mathrm{nt} 647-671^{\mathrm{c}}$ & CAGCCAAAGAGTCCGTGGTGCGAAG & 1762 & 72 \\
\hline ERadF & nt973-994d & AGCCACCCATAGTTTATTCTGA & 284 & 60 \\
\hline ERadR & nt $1237-1256^{\mathrm{d}}$ & GCATTTCCCTTGATTCCTGT & & \\
\hline ERßdF & nt1198-1216 b & GCCCAGCAAACCATTCACG & 263 & 60 \\
\hline ER $\beta \mathrm{dR}$ & nt1441-1460 b & CCTCTACGCATTTCCCCTCG & & \\
\hline $\mathrm{ER} \alpha \mathrm{F}$ & nt1-16 & CTCCTTGCTCACTGCC & 1833 & 55 \\
\hline ERaR & nt $1817-1833^{\circ}$ & GTGCTGGGTTTCTCATA & & \\
\hline ER $\beta F$ & $\mathrm{nt} 81-97^{\mathrm{d}}$ & GTTGTTTTGTGGAGGAC & 2288 & 56 \\
\hline ER $\beta R$ & nt2352-2368 & TCTGAAAGAGGAGGTTG & & \\
\hline OVAdF & $\mathrm{nt} 203-219^{\mathrm{e}}$ & ATCTTCGCCCCCTTGAG & 235 & 60 \\
\hline OVAdR & $\mathrm{nt} 420-437^{\mathrm{e}}$ & CGTGAAGTCTGGCAAAGC & & \\
\hline$\beta$-actinF & $\mathrm{nt} 558-577^{\mathrm{f}}$ & CCCATCTACGAAGGCTACGC & 250 & 60 \\
\hline$\beta$-actinR & nt $687-707^{\mathrm{f}}$ & CTTGATGTCACGCACAATTTC & & \\
\hline \multirow[t]{2}{*}{ ER $\alpha$-siRNA } & nt1147-1165 & GUGCUUGGUUAGAGAUACUTT & & \\
\hline & & AGUAUCUCUAACCAAGCACTT & & \\
\hline
\end{tabular}

${ }^{\mathrm{a} B a s e d}$ on reported gallus ER $\alpha$ sequence (accession No. NM_205183). ${ }^{\mathrm{b}}$ Based on reported gallus ER $\beta$ sequence (accession No. NM_204794). 'Based on reported pigeon ER $\beta$ sequence (accession No. JX413116). 'Based on reported pigeon ER $\alpha$ sequence (accession No. JX413115). ${ }^{\circ}$ Based on the obtained pigeon OVA sequence (accession No. NM_205152). ${ }^{\mathrm{f}}$ Based on reported gallus $\beta$-actin cDNA sequence (accession No. NM_205518.1). AT = annealing temperature.

PCR was performed using $2 \mu \mathrm{L}$ cDNA in a mixture containing $20 \mu \mathrm{L}(1 \mathrm{U})$ Ex-Taq polymerase (Takara), $160 \mu \mathrm{M}$ each dNTP, and $4 \mu \mathrm{L} 5 \mathrm{X}$ buffer, which was supplied by the manufacturer. The PCR conditions were 5 min at $94^{\circ} \mathrm{C}$ followed by 35 cycles at $94^{\circ} \mathrm{C}$ for 30 $\mathrm{s}, 50^{\circ}-58^{\circ} \mathrm{C}$ for $30 \mathrm{~s}$, and $72^{\circ} \mathrm{C}$ for $30-120 \mathrm{~s}$. After a 10 -min final extension step at $72^{\circ} \mathrm{C}$, the products were visualized on $1 \%$ agarose gel using SYBR Green I (Invitrogen) staining. All 
fragments obtained were cloned into the PMD-19T plasmid vector (Takara), and sequenced by Invitrogen. The full-length complete coding sequences (CDSs) of pigeon ER $\alpha$ and ER $\beta$ were obtained by assembling these fragments, and ultimately determined by evaluating which independent clones contained the whole open reading frame regions using $E R \alpha F / R$ and $E R \beta F / R$.

\section{Sequence alignment and phylogenetic analysis}

Amino acid sequences of the pigeon ER $\alpha$ and ER $\beta$ were predicted based on the open reading frames of the expressed nucleotide sequences (http://www.ncbi.nlm.nih.gov/gorf/gorf. $\mathrm{html}$ ). Amino acid sequences were aligned using CLUSTALX, version 2.0. A protein phylogenetic tree was generated with the MEGA software using the neighbor-joining method.

ER sequences used for the phylogenetic analysis were as follows: Alligator mississippiensis (alligator, ER $\alpha, \mathrm{AB} 115909$; ER $\beta, \mathrm{AB} 548298$ ); Bos taurus (cow, ER $\alpha, \mathrm{NM}$ 001024231; ER $\beta$, Y18017); Callithrix jacchus (marmoset, ER $\beta$, AF393816); Ceratotherium simum simum (rhinoceros, ER $\alpha$, JN997452; ER $\beta$, JN997453); Coturnix japonica (quail, ER $\beta$, AF045149); Cynops pyrrhogaster (newt, ER $\beta$, AB524909); Elaphe quadrivirgata (rat snake, ER $\beta$, AB548297); Equus caballus (horse, ER $\alpha$, NM 001081772); Eublepharis macularius (gecko, ER $\beta$, AB240529); Felis catus (cat, ER $\alpha, \mathrm{NM}_{-}$001024231); Gallus gallus (chicken, ER $\alpha$, HQ340611; ER $\beta$, NM_204794); Gyps africanus (vulture, ER $\alpha$, AB447536); Homo sapiens (human, ER $\alpha, \mathrm{JF} 810888$; ER $\beta$, AF051427); Hynobius tokyoensis (Tokyo salamander, ER $\beta$, AB524911); Mus musculus (mouse, ER $\alpha$, NM_007956; ER $\beta$, MMU81451); Ovis aries (sheep, ER $\beta$, NM_001009737); Papio anubis (olive baboon, ER $\alpha$, NM_001164587; ER $\beta$, NM_001164588); Pseudemys nelsoni (turtle, ER $\alpha$, AB301060; ER $\beta$, AB548299); Rana rugosa (Japanese wrinkled frog, ER $\beta$, FJ828859); Rattus norvegicus (rat, ER $\alpha$, AB477039; ER $\beta$, AB190769); Sturnus vulgaris (common starling, ER $\beta$, AF113513); Sus scrofa (pig, ER $\alpha$, NM_214220; ER $\beta$, AF267736); Taeniopygia guttata (zebra finch, ER $\alpha$, NM_001076701); and Xenopus tropicalis (clawed frog, ER $\beta, \mathrm{BC} 171194)$.

\section{qPCR analysis}

The ABI 7300 system (Applied Biosystems, Foster City, CA, USA) and THUNDERBIRD $^{\mathrm{TM}} \mathrm{SYBR}^{\circledR}$ qPCR Mix (Toyobo, Osaka, Japan) were used for qPCR to analyze mRNA levels of the ER $\alpha$ and $\mathrm{ER} \beta$ proteins. Assays were performed in a $50-\mu \mathrm{L}$ system containing $5 \mu \mathrm{L}$ cDNA template, $10 \mu \mathrm{L}$ THUNDERBIRD ${ }^{\mathrm{TM}}$ SYBR $^{\circledR}$ qPCR Mix, 0.4 $\mu \mathrm{L}$ ROX reference dye (Toyobo), $0.4 \mathrm{mM}$ ER $\alpha \mathrm{dF} / \mathrm{R}$ and $\mathrm{ER} \beta \mathrm{dF} / \mathrm{R}$ or $\beta$-actinF/R, primers for the target genes or $\beta$-actin (control). The primer sequences of $\beta$-actin were obtained from the National Center for Biotechnology Information. The thermal cycler parameters were $94^{\circ} \mathrm{C}$ for $2 \mathrm{~min}, 40$ cycles of denaturation at $94^{\circ} \mathrm{C}$ for $10 \mathrm{~s}$, and annealing and extension at $60^{\circ} \mathrm{C}$ for $30 \mathrm{~s}$. Pure water replaced the template as a negative control, and each sample was replicated three times. The relative expression levels of pigeon ER $\alpha$ and $E R \beta$ were determined by $2^{-\Delta C t}$ $\left(\Delta \mathrm{Ct}=\mathrm{Ct}_{\text {target gene }}-\mathrm{Ct}_{\beta \text {-actin }}\right)$. Data are reported as means \pm standard error (SE) of the mean.

\section{qPCR efficiency and statistical analysis}

The amplification efficiency of each primer used for the qPCR analysis was estimated by step dilutions. A standard curve with a 5-point 10-fold dilution series was used to calculate 
the amplification efficiency. The formula was as follows: $\mathrm{E}=10^{-1 / \text { slope }}-1$.

Significant differences in expression were determined by the Student $t$-test. Differences were considered to be significant when $\mathrm{P}$ values were $<0.05$.

\section{RESULTS}

\section{Cloning and sequence analysis of pigeon ER $\alpha$ and ER $\beta$}

Pigeon ER $\alpha$ and ER $\beta$ cDNAs were cloned from the oviduct and ovary, respectively. The complete CDSs obtained from these genes closely matched those of other avian ER $\alpha$ and ER $\beta$ sequences. The pigeon ER $\alpha$ cDNA sequence was 1833 bp in length (GenBank accession No. JX413115). The encoded pigeon ER $\alpha$ was a 587 -amino acid peptide. The full-length pigeon ER $\beta$ clone generated was 2193 bp in length (GenBank accession No. JX413116) and encoded a protein of 553 amino acids.

Pigeon ER $\alpha$ and ER $\beta$ contain the functional structure of nuclear receptors. Multiple alignment of the two ERs showed that pigeon ERs are highly similar to reptilian and avian ERs (Figure 1A and B).

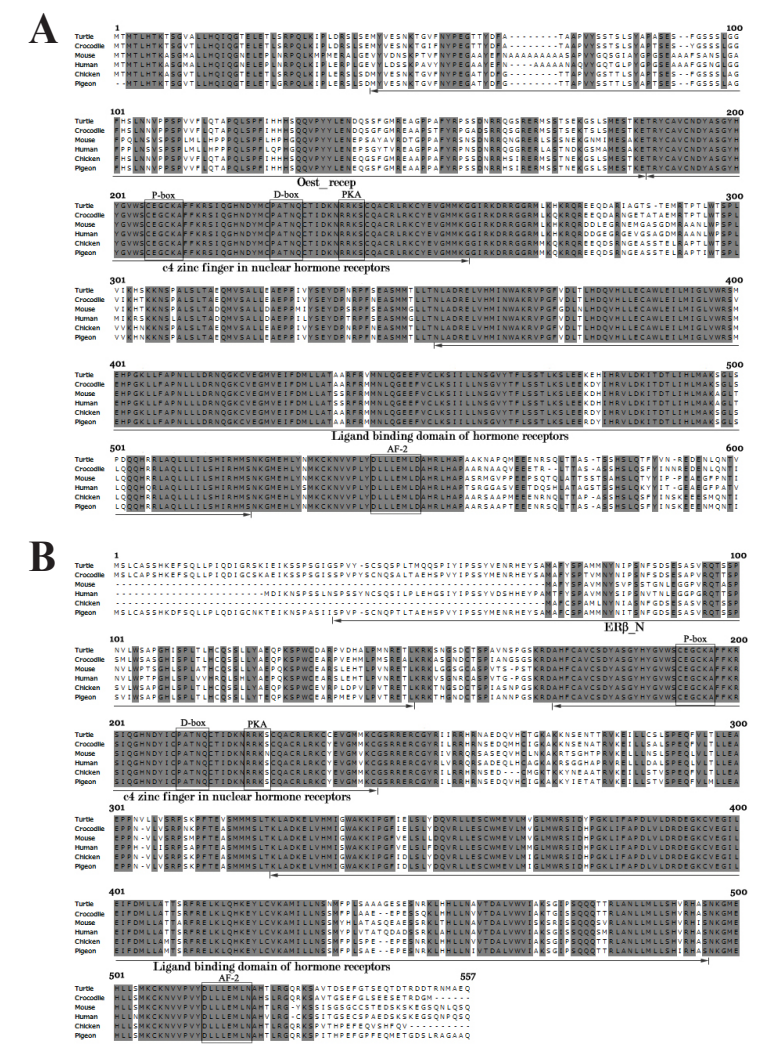

Figure 1. Alignment of the deduced amino acid sequences of estrogen receptors in turtle, crocodile, mouse, human, chicken, and pigeon. "-" indicates deletion of an amino acid. The shade regions indicate conserved amino acids among six species. A. Aligned amino acid of pigeon ER $\alpha$ with ER $\alpha$ of other species. B. Aligned amino acid of pigeon ER $\beta$ with ER $\beta$ of other species. 
Phylogenetic analysis revealed that pigeon ER $\alpha$ and $E R \beta$ clustered into two subclades (Figure 2). Additionally, these two proteins were more similar to those of reptilians and avians than to those of other vertebrates.

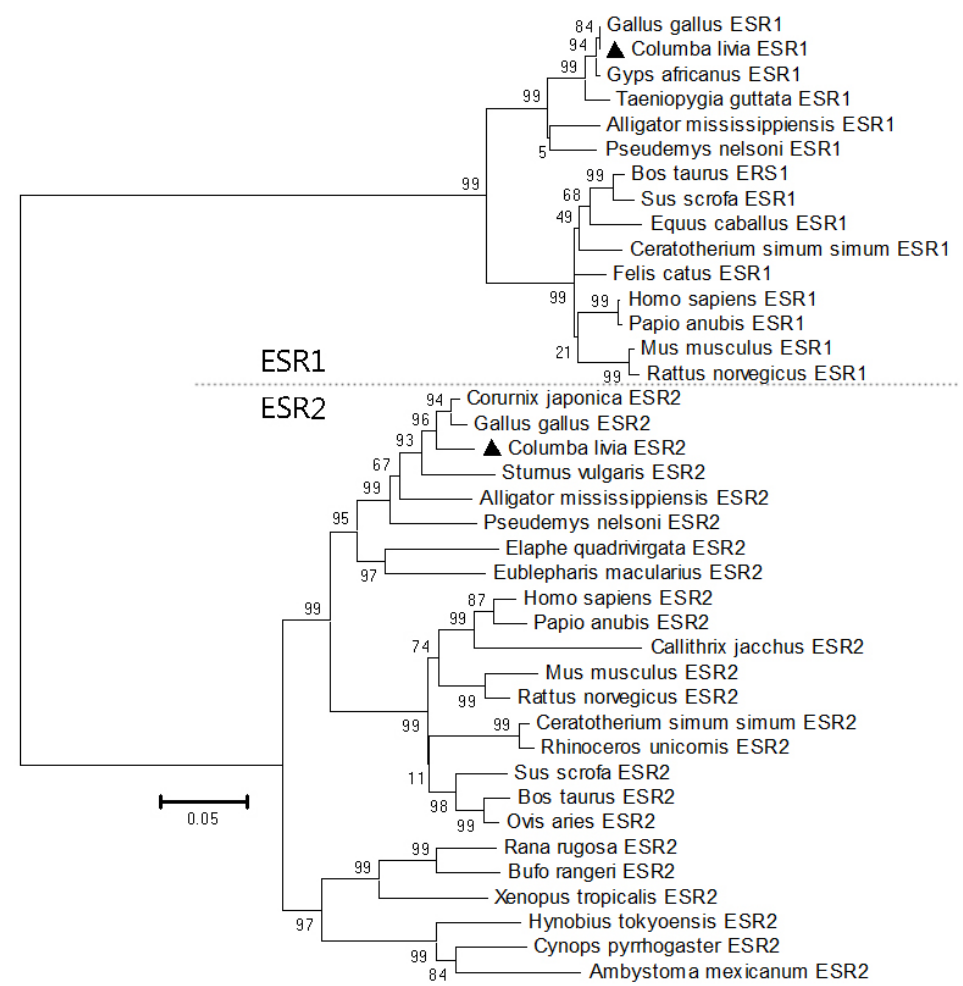

Figure 2. Estrogen receptor (ER) neighbor-joining tree showing phylogenetic relationship between pigeon ERs and ERs from other species. The phylogenic tree was constructed using the MEGA program with the bootstrap test of phylogeny, neighbor-joining method and bootstrap re-sampling for 1000 times. The length of branch reflects estimated numbers of substitutions along each branch. The scale bar indicates 0.05 expected amino acid substitutions per site.

\section{Expression of pigeon ERs in various tissues}

The expression of pigeon ER $\alpha$ and $E R \beta$ in various tissues was investigated by qPCR using the primers $\mathrm{ER} \alpha \mathrm{dF} / \mathrm{R}$ (Figure $3 \mathrm{~A}$ ) and $\mathrm{ER} \beta \mathrm{dF} / \mathrm{R}$ (Figure 3B). The expression profiles of these two ER mRNAs were different. Pigeon ER $\alpha$ mRNA was highly expressed in the oviduct, whereas ER $\beta$ was highly expressed in the ovary and kidney.

Relative standard curves showed very high amplification efficiencies for all primers (Figure 4).

\section{Effect of 17ß-estradiol on gene expression of ER $\alpha$ in POECs}

To examine whether $17 \beta$-estradiol could induce the expression of ER genes in the pigeon oviduct, primary cultured POECs were treated with $17 \beta$-estradiol for $24 \mathrm{~h}$. The working concentrations of $17 \beta$-estradiol were $10^{-7}, 10^{-8}, 10^{-9}, 10^{-10} \mathrm{M}$, and 0 . Figure 5 shows regulation of pigeon ER $\alpha$ expression by $17 \beta$-estradiol. The expression level of ER $\alpha$ was down-regulated when treated with $17 \beta$-estradiol. 


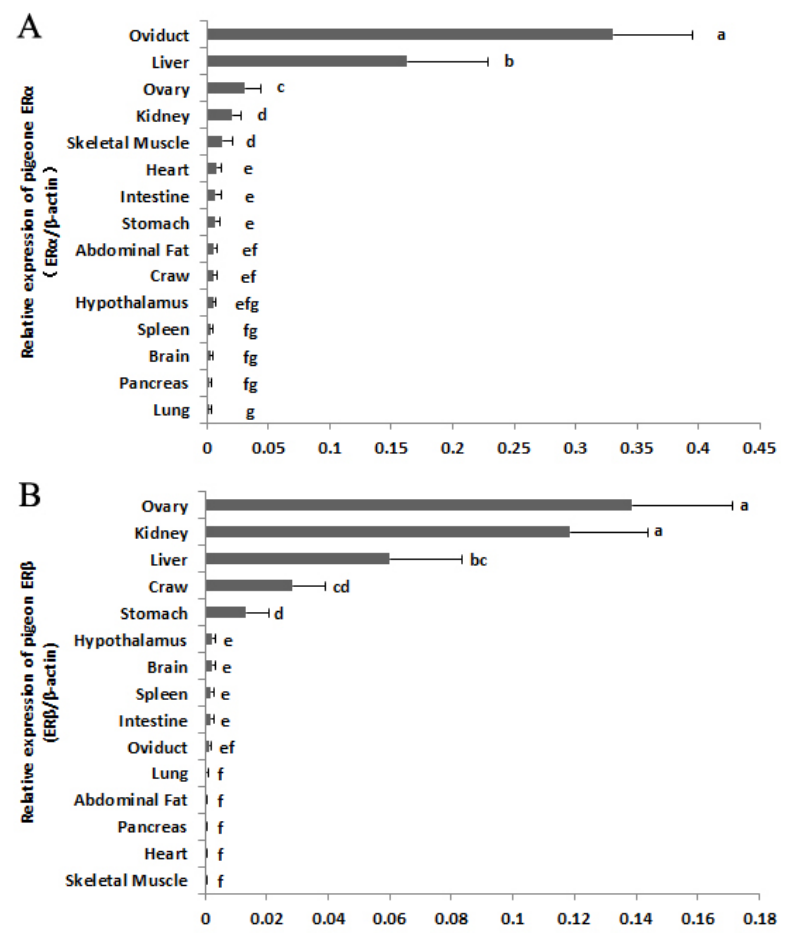

Figure 3. Relative expression of the mRNA for pigeon ER $\alpha$ and $E R \beta$ in various tissues. Expression levels of ER $\alpha$ (A) and $\operatorname{ER} \beta(\mathbf{B})$ in 15 tissues were determined by q-PCR and normalized to that of $\beta$-actin. Each column represents the means of 8 individual female pigeons $\pm \mathrm{SE}$. Different letters indicate significant difference at $\mathrm{P}<0.05$.
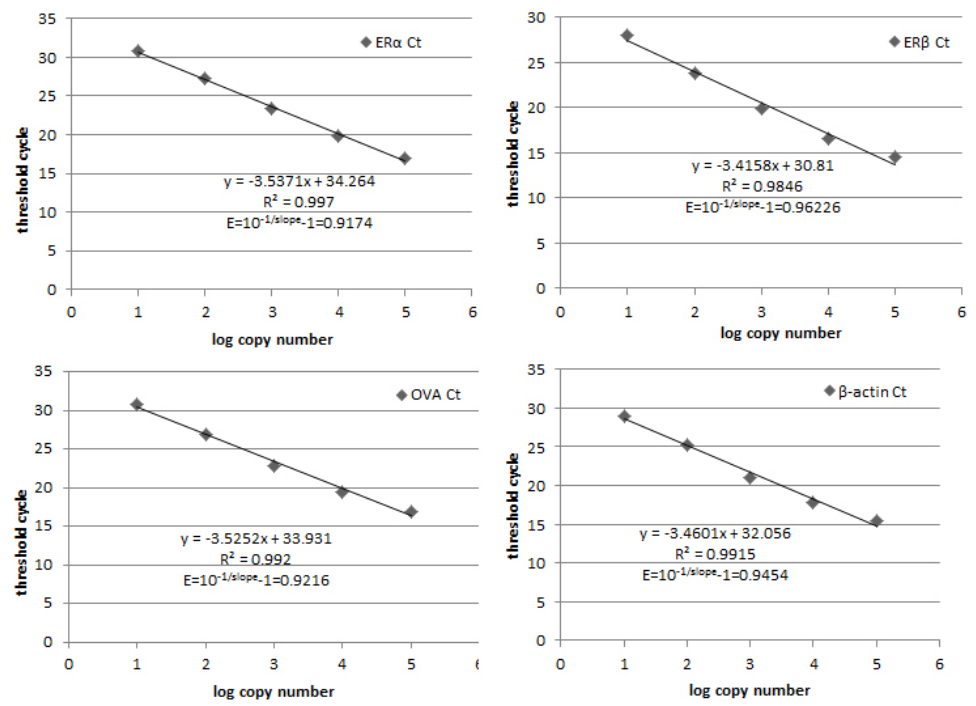

Figure 4. Relative standard curves generated by plotting cycles at threshold fluorescence (Ct) against the logarithmic values of liver and oviduct cDNA amounts (mean $\pm \mathrm{SE} ; \mathrm{N}=3$ ). Quantities of liver and oviduct cDNA were expressed as dilution factors of the cDNA preparation $\left(1,10^{-1}, 10^{-2}, 10^{-3}\right.$, and $\left.10^{-4}\right)$. Correlation coefficients $\left(\mathrm{R}^{2}\right)$ and amplification efficiencies $(\mathrm{E})$ of different primer pairs are shown in the figure. 


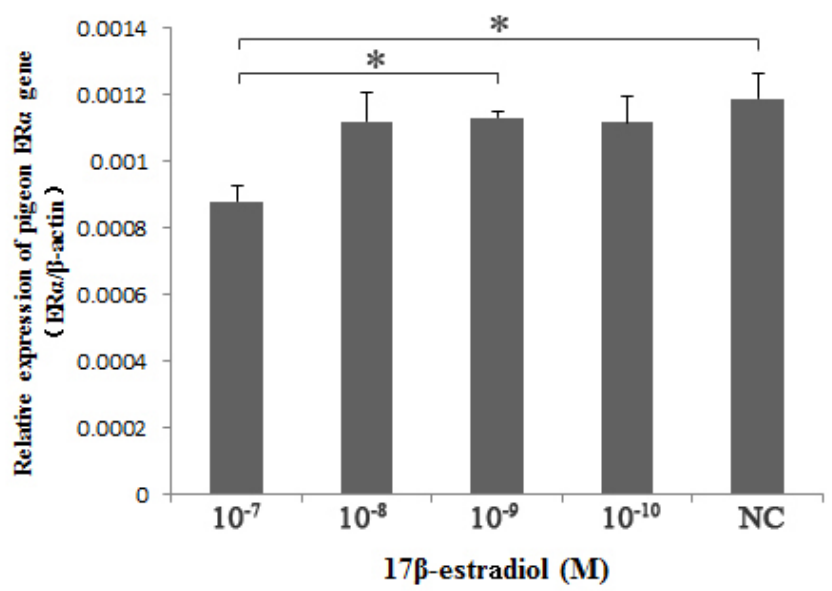

Figure 5. Effects of $17 \beta$-estradiol on the mRNA expression of ER $\alpha$ in pigeon oviduct epithelial cells. The concentrations of $17 \beta$-estrodiol were $10^{-7}, 10^{-8}, 10^{-9}, 10^{-10}$, and 0 (NC) $\mathrm{M}$. The gene expression was determined by qPCR, normalized to $\beta$-actin. Values are means $\pm \mathrm{SE}(\mathrm{N}=3) . * \mathrm{P}<0.05$.

\section{Effect of ER $\alpha$ expression on OVA in POECs}

To investigate the effect of ER $\alpha$ in mediating pigeon OVA expression in primary cultured POECs, an siRNA knockdown technique was utilized to reduce the expression of the pigeon ER $\alpha$ (53.09\% suppression, $\mathrm{P}<0.05$; Figure $6 \mathrm{~A})$. Total RNA was extracted from knockdown and control POECs, respectively, and used for qPCR. OVA mRNA levels were increased 4.08-fold $(\mathrm{P}<0.01$; Figure 6B) in the ER $\alpha$ knockdown POECs.

A

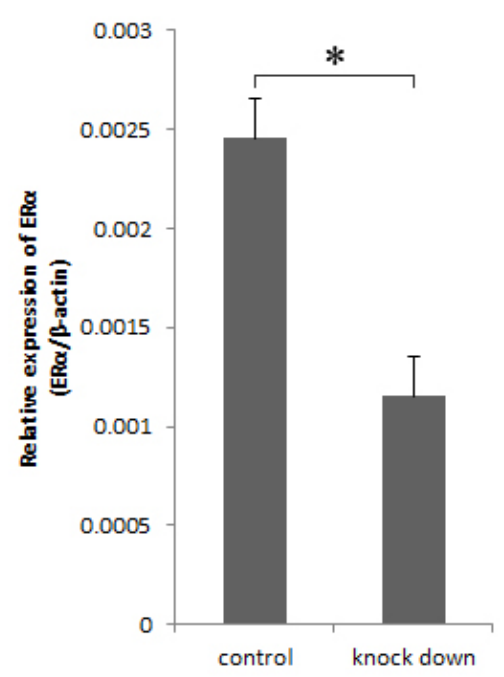

B

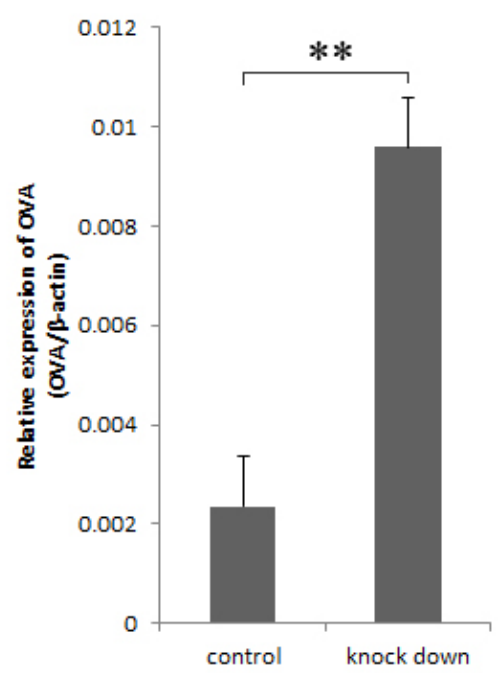

Figure 6. Effects of the ER $\alpha$ knockdown on the expression of mRNA for ER $\alpha(\mathbf{A})$ and OVA (B). Relative expression level of ER $\alpha$ and OVA were determined by qPCR, and the $\beta$-actin was used as a reference gene. Results are reported as mean $\pm \mathrm{SE}$ of triplicate cultures. ${ }^{*} \mathrm{P}<0.05,{ }^{*} \mathrm{P}<0.01$. 


\section{DISCUSSION}

In the present study, we designed and utilized degenerate primers based on the sequences of ERs from other bird species, and obtained full-length sequences of pigeon ER $\alpha$ and ER $\beta$. We observed that both pigeon ER $\alpha$ and ER $\beta$ CDSs showed strong similarity to the same receptors from other avian and reptilian species. The zinc finger DNA-binding domains between pigeon ER $\alpha$ and ER $\beta$ are highly conserved and contain the functional elements of these receptors, including a P-box, D-box, PKA sit, and estrogen-responsive element (Figure 1), which are critical for target gene recognition, reorganization, and regulation (Joel et al., 1998; Vanacker et al., 1999). Two transcriptional activation functions (AFs) exist in pigeon ERs: one, AF-1, is located within the N-terminal region, and the other is the moderately conserved AF-2 sequence that is embedded within the E/F domain. The weakly conservative AF-1 may be critical in explaining how ERs bind to the same response elements yet differentially regulate target gene transcription in vivo (Bain et al., 2007). AF-2 is dependent on binding to recruiting proteins that contain helical LXXLL motifs for proper function. AF-1 may also functionally synergize with AF-2 to activate the transcription of target genes (Takimoto et al., 2003).

The pigeon ER $\alpha$ and ER $\beta$ clustered with those of other known vertebrates (Figure 2). Phylogenetic studies of nuclear and mitochondrial genes have supported the hypothesis that birds are more closely related to reptilian species than to other vertebrates (Cao et al., 2000; Katsu et al., 2006; Marquez et al., 2011). ER $\alpha$ and ER $\beta$ sequences of the American alligator clustered within a branch of a single clade comprising birds and crocodilians, while mammals clustered within another branch of this clade (Katsu et al., 2004). Our results further support the hypothesis that pigeons are a sister group to crocodilians and birds.

Pigeon ER mRNAs were detected in various organs (brain, craw, fat, heart, hypothalamus, intestine, kidney, liver, lung, ovary, oviduct, pancreas, skeletal muscle, spleen, stomach, and testis), implying that ER functions widely in pigeons. Similar to that of humans, pigeon ER $\alpha$ was highly expressed in the oviduct and expressed at low levels in the pancreas and lung (Bookout et al., 2006). ER $\beta$ was detected to be highly expressed in pigeon ovary and kidney tissues, consistent with reports in mammals. The expression of pigeon ER $\beta$ in the oviduct was relatively low. These results demonstrate that ER $\alpha$ mRNA predominates over that of ER $\beta$ in the oviduct.

Regulation of ER by estrogen has not been clearly characterized. In vivo, ovine uterine cells responded to estrogen treatment by up-regulating the transcription of ER $\alpha$ mRNA (Ing and Tornesi, 1997; Robertson et al., 2001). Estrogen also increased ER $\alpha$ mRNA levels in ZR75 (Clayton et al., 1997) and Ishikawa cells (Robertson et al., 2002). However, estrogen treatment decreased ER $\alpha$ mRNA in ECC-1 (Farnell and Ing, 2003) and MCF-7 cells (Saceda et al., 1998). This effect was believed to be caused by the relatively low stability of ER $\alpha$ mRNA. In the present study, we found that treatment of POECs with $17 \beta$-estradiol resulted in a decrease in the expression of ER $\alpha$ mRNA. This finding provides new insight in the regulation of ER $\alpha$ in avian oviducts. Moreover, the expression level of ER $\alpha$ was down-regulated when treated with a physiological dose of $17 \beta$-estradiol $\left(10^{-7} \mathrm{M}\right)$. Therefore, we conclude that the expression of pigeon ER $\alpha$ can be regulated by $17 \beta$-estradiol in a dose-dependent manner.

Sanders and McKnight (1985) reported that a combination of progesterone and estrogen treatment expressed more OVA mRNA than an estrogen-only treatment in cultured chicken oviduct cells. Moreover, progesterone was able to repress the expression of ER $\alpha$ (Hsueh et al., 1976; Kraus and Katzenellenbogen, 1993). Together, these findings suggest that ER $\alpha$ inhibits the expression of OVA mRNA in oviduct epithelial cells. In this study, we examined 
how ER $\alpha$ regulated OVA mRNA expression in POECs using the siRNA method. Consistent with our hypothesis, the knockdown of ER $\alpha$ significantly up-regulated OVA mRNA, thereby indicating that ER $\alpha$ plays an important role in OVA transcription. However, the mechanisms underlying the regulation of pigeon oviduct secretion of OVA and other tissues by ER $\alpha$ require additional study.

In conclusion, full-length cDNAs encoding pigeon ER $\alpha$ and ER $\beta$ were here cloned and sequenced for the first time. The pigeon ER $\alpha$ was predominantly expressed in the oviduct, whereas ER $\beta$ was highly expressed in the ovary. In cultured POECs, the expression of ER $\alpha$ was down-regulated by $17 \beta$-estradiol, and the knockdown of ER $\alpha$ promoted the expression of OVA mRNA.

\section{ACKNOWLEDGMENTS}

Research supported by the Science and Technology Specific Project for Enriching People and Strengthening Country Economy, China, and the Breeding Specific Project of the “Twelfth Five Plan” of Zhejiang Province, China (project \#2012C12906-17).

\section{REFERENCES}

Bain DL, Heneghan AF, Connaghan-Jones KD and Miura MT (2007). Nuclear receptor structure: implications for function. Anпи. Rev. Physiol. 69: 201-220.

Bookout AL, Jeong Y, Downes M, Yu RT, et al. (2006). Anatomical profiling of nuclear receptor expression reveals a hierarchical transcriptional network. Cell 126: 789-799.

Borras M, Hardy L, Lempereur F, el Khissiin AH, et al. (1994). Estradiol-induced down-regulation of estrogen receptor. Effect of various modulators of protein synthesis and expression. J. Steroid Biochem. Mol. Biol. 48: 325-336.

Cao Y, Sorenson MD, Kumazawa Y, Mindell DP, et al. (2000). Phylogenetic position of turtles among amniotes: evidence from mitochondrial and nuclear genes. Gene 259: 139-148.

Chen H, Zhang Y, Li S, Lin M, et al. (2011). Molecular cloning, characterization and expression profiles of three estrogen receptors in protogynous hermaphroditic orange-spotted grouper (Epinephelus coioides). Gen. Comp. Endocrinol. 172: 371-381.

Clayton SJ, May FE and Westley BR (1997). Insulin-like growth factors control the regulation of oestrogen and progesterone receptor expression by oestrogens. Mol. Cell Endocrinol. 128: 57-68.

Farnell YZ and Ing NH (2003). The effects of estradiol and selective estrogen receptor modulators on gene expression and messenger RNA stability in immortalized sheep endometrial stromal cells and human endometrial adenocarcinoma cells. J. Steroid Biochem. Mol. Biol. 84: 453-461.

Glass CK (1994). Differential recognition of target genes by nuclear receptor monomers, dimers, and heterodimers. Endocr. Rev. 15: 391-407.

Green S, Walter P, Kumar V, Krust A, et al. (1986). Human oestrogen receptor cDNA: sequence, expression and homology to v-erb-A. Nature 320: 134-139.

Hiroi H, Inoue S, Watanabe T, Goto W, et al. (1999). Differential immunolocalization of estrogen receptor alpha and beta in rat ovary and uterus. J. Mol. Endocrinol. 22: 37-44.

Hsueh AJ, Peck EJ Jr and Clark JH (1976). Control of uterine estrogen receptor levels by progesterone. Endocrinology 98: 438-444.

Ing NH and Tornesi MB (1997). Estradiol up-regulates estrogen receptor and progesterone receptor gene expression in specific ovine uterine cells. Biol. Reprod. 56: 1205-1215.

Joel PB, Smith J, Sturgill TW, Fisher TL, et al. (1998). pp90rsk1 regulates estrogen receptor-mediated transcription through phosphorylation of Ser-167. Mol. Cell Biol. 18: 1978-1984.

Jung JG, Park TS, Kim JN, Han BK, et al. (2011). Characterization and application of oviductal epithelial cells in vitro in Gallus domesticus. Biol. Reprod. 85: 798-807.

Kasperczyk K, Bajek A, Joachimiak R, Walasik K, et al. (2012). In vitro optimization of the Gallus domesticus oviduct epithelial cells culture. Theriogenology 77: 1834-1845. 
Katsu Y, Bermudez DS, Braun EL, Helbing C, et al. (2004). Molecular cloning of the estrogen and progesterone receptors of the American alligator. Gen. Comp. Endocrinol. 136: 122-133.

Katsu Y, Kohno S, Oka T, Mitsui N, et al. (2006). Molecular cloning of estrogen receptor alpha (ERalpha; ESR1) of the Japanese giant salamander, Andrias japonicus. Mol. Cell Endocrinol. 257-258: 84-94.

Kenealy MR, Flouriot G, Sonntag-Buck V, Dandekar T, et al. (2000). The 3'-untranslated region of the human estrogen receptor alpha gene mediates rapid messenger ribonucleic acid turnover. Endocrinology 141: 2805-2813.

Kohler PO, Grimley PM and O'Malley BW (1969). Estrogen-induced cytodifferentiation of the ovalbumin-secreting glands of the chick oviduct. J. Cell Biol. 40: 8-27.

Kraus WL and Katzenellenbogen BS (1993). Regulation of progesterone receptor gene expression and growth in the rat uterus: modulation of estrogen actions by progesterone and sex steroid hormone antagonists. Endocrinology 132: 2371-2379.

Krust A, Green S, Argos P, Kumar V, et al. (1986). The chicken oestrogen receptor sequence: homology with v-erbA and the human oestrogen and glucocorticoid receptors. EMBO J. 5: 891-897.

Kuiper GG, Enmark E, Pelto-Huikko M, Nilsson S, et al. (1996). Cloning of a novel receptor expressed in rat prostate and ovary. Proc. Natl. Acad. Sci. U. S. A. 93: 5925-5930.

Lakaye B, Foidart A, Grisar T and Balthazart J (1998). Partial cloning and distribution of estrogen receptor beta in the avian brain. Neuroreport 9: 2743-2748.

Marquez EC, Traylor-Knowles N, Novillo-Villajos A and Callard IP (2011). Cloning of estrogen receptor alpha and aromatase cDNAs and gene expression in turtles (Chrysemys picta and Pseudemys scripta) exposed to different environments. Comp. Biochem. Physiol. C Toxicol. Pharmacol. 154: 213-225.

Nilsson S, Makela S, Treuter E, Tujague M, et al. (2001). Mechanisms of estrogen action. Physiol. Rev. 81: 1535-1565.

Palmiter RD and Wrenn JT (1971). Interaction of estrogen and progesterone in chick oviduct development. 3. Tubular gland cell cytodifferentiation. J. Cell Biol. 50: 598-615.

Peng SS, Chen CY and Shyu AB (1996). Functional characterization of a non-AUUUA AU-rich element from the c-jun proto-oncogene mRNA: evidence for a novel class of AU-rich elements. Mol. Cell Biol. 16: 1490-1499.

Robertson JA, Zhang Y and Ing NH (2001). ICI 182,780 acts as a partial agonist and antagonist of estradiol effects in specific cells of the sheep uterus. J. Steroid Biochem. Mol. Biol. 77: 281-287.

Robertson JA, Farnell Y, Lindahl LS and Ing NH (2002). Estradiol up-regulates estrogen receptor messenger ribonucleic acid in endometrial carcinoma (Ishikawa) cells by stabilizing the message. J. Mol. Endocrinol. 29: 125-135.

Saceda M, Lindsey RK, Solomon H, Angeloni SV, et al. (1998). Estradiol regulates estrogen receptor mRNA stability. $J$. Steroid Biochem. Mol. Biol. 66: 113-120.

Sanders MM and McKnight GS (1985). Chicken egg white genes: multihormonal regulation in a primary cell culture system. Endocrinology 116: 398-405.

Takimoto GS, Tung L, Abdel-Hafiz H, Abel MG, et al. (2003). Functional properties of the N-terminal region of progesterone receptors and their mechanistic relationship to structure. J. Steroid Biochem. Mol. Biol. 85: 209-219.

Treilleux, Peloux N, Brown M and Sergeant A (1997). Human estrogen receptor (ER) gene promoter-P1: estradiolindependent activity and estradiol inducibility in ER+ and ER- cells. Mol. Endocrinol. 11: 1319-1331.

Vanacker JM, Pettersson K, Gustafsson JA and Laudet V (1999). Transcriptional targets shared by estrogen receptorrelated receptors (ERRs) and estrogen receptor (ER) alpha, but not by ERbeta. EMBO J. 18: 4270-4279. 